\title{
Pengembangan sistem logistik produk halal di Indonesia
}

\author{
Reza Ashari* \\ Perencana Muda, Bappeda Provinsi Kepulauan Bangka Belitung, Indonesia.
}

\begin{abstract}
ABSTRAK
Penyediaan produk halal merupakan salah satu kondisi yang harus dilakukan dalam negara yang beragama muslim dan memberikan sertifikasi halal pada produk tersebut. Penelitian ini menggunakan metode review literatur dari berbagai jurnal yang berkaitan dengan logistik produk halal dengan sub tema penelitian kerangka konsep penelitian dan strategi pengembangan logistik produk halal. Hasil penelitian menunjukkan bahwa ada 2 konsep penting dalam logistik produk halal, yaitu integrasi produk halal dan segregasi kelayakan produk serta sistem logistik. Kedua konsep ini saling berkaitan satu dengan lainnya. Integritas produk halal berkaitan dengan tindakan pencegahan terjadinya kontaminasi produk halal dengan non-halal dan segregasi berkaitan dengan pemisahan produk halal dan non-halal. Strategi dalam pengembangan sistem logistik produk halal ada dua, yaitu party logistic dengan 4 klasifikasi, yaitu $1 \mathrm{PL}, 2 \mathrm{PL}, 3 \mathrm{PL}, 4 \mathrm{PL}$, dan $5 \mathrm{PL}$ serta manajemen pengetahuan. Teknologi blockchain menjadi faktor dalam pengembangan sistem logistik halal sehingga kualitas produk halal dan kinerja keuangan menjadi baik, serta terjadi transparansi informasi tentang kehalalan produk yang disediakan dari penyedia produk hingga penjualan. Aspek yang terpenting dalam pengembangan sistem logistik produk halal adalah integritas produk halal yang difokuskan pada pencegahan kontaminan produk dengan konsep pembersihan secara sertu dan integrasi strategi 5 PL dengan manajemen pengetahuan dan inovasi teknologi blockchain. Dengan demikian, pengembangan sistem logistik di Indonesia menjadi lebih baik.
\end{abstract}

Kata kunci: Blockchain, Halal logistik, Integritas produk halal.

(C) 2017 Pusat Kajian Halal ITS. All rights reserved.

\section{Pendahuluan}

Produk halal merupakan produk makanan dan minuman yang layak dikonsumsi oleh masyarakat muslim serta diberi label halal dalam kemasannya. Dalam pelaksanaannya, penyampaian produk makanan dan minuman ini kepada konsumen memerlukan sistem manajemen yang baik dan berkualitas. Sistem manajemen yang mengatur distribusi serta penyimpanan produk ini dinamakan sebagai sistem logistik halal. Sistem logistik halal merupakan bagian dari manajemen rantai pasok yang terdapat dalam industri makanan halal. Secara global, produk makanan halal tertinggi dalam pemasaran dan penjualannya adalah daging halal dengan persentase sebesar 47,79\% pada tahun 2019 dan diperkirakan akan mengalami kenaikan pada tahun 2030 dengan persentase lebih dari 80\%. Produk halal

\footnotetext{
* Corresponding author. Tel: 085382997796; Fax: -

Email address: asharireza29@gmail.com
} 
yang mempunyai tingkat pemasaran yang rendah adalah sayur dan buah halal dengan persentase di bawah $40 \%$ dan susu halal menjadi produk yang paling cepat pertumbuhan penjualannya [1].

Indonesia merupakan salah satu negara muslim terbesar di dunia. Produk makanan dan minuman yang berasal dari luar maupun dalam negeri harus diuji kehalalannya. Uji kehalalan makanan dan minuman dilakukan oleh MUI (Majelis Ulama Indonesia) melalui LPPOM (Lembaga Pengujian Pangan Obat-Obatan dan Kosmetika Majelis Ulama Indonesia). Pada tahun 2019, jumlah perusahaan yang mendaftar untuk pengujian produknya sebesar 13.951 perusahaan dan mengalami kenaikan dibandingkan dengan tahun 2018 sebesar 11.249 perusahaan. Kemudian jumlah produk yang diuji tahun 2019 sebesar 274.796 produk. Jika dibandingkan dengan tahun 2018, angka tersebut mengalami kenaikan 204.222 produk. Pencapaian kenaikan jumlah produk dan perusahaan berbanding terbalik dengan pencapaian pemberian sertifikat halal produk. Jumlah sertifikat halal yang diberikan pada tahun 2019 mengalami penurunan dibandingkan dengan tahun 2018, yaitu dari 17.398 menjadi 15.495 sertifikat halal [2].

Penurunan jumlah penerima sertifikat halal produk tentu menjadi permasalahan utama dalam pemasaran produk di wilayah yang mayoritas penduduknya beragama Islam. Ketiadaan label halal pada produk yang dipasarkan dapat memberikan dampak negatif terhadap keuntungan atau pendapatan dari perusahaan yang memasarkan produknya. Seperti diketahui bahwa Asia Pasifik merupakan pangsa yang besar dalam pemasaran produk halal tersebut. Untuk itu, dalam pemasaran produk halal memerlukan strategi dan manajemen yang baik terutama dalam logistik. Faktor yang menjadi permasalahan logistik halal adalah rendahnya sertifikasi halal secara internasional, panduan kehalalan yang ambigu, keuangan kolaborasi dan koordinasi, rendahnya permintaan serta rendahnya standar dalam mengukur efektifitas pembiayaan (cost-effective) [3]. Tantangan atau permasalahan ini menjadi motivasi bagi pemerintah untuk menyediakan pelayanan logistik halal secara berkualitas dan penyediaan standarisasi dalam penghantaran produk pada konsumen.

Penulisan makalah ini bertujuan untuk mengkaji konsep, strategi, dan inovasi dalam pengembangan logistik produk halal di Indonesia untuk menyediakan produk halal yang berkualitas pada konsumen. Kajian dalam penulisan ini menggunakan beberapa literatur yang terkait dengan tema penelitian yang berkaitan dengan logistik halal.

\section{Bahan dan metode}

\subsection{Bahan}

Penelitian ini bersumber pada beberapa literatur yang berkaitan dengan logistik halal produk makanan dan minuman yang beredar di pasaran. Literatur yang diambil merupakan jurnal dan website dengan pengambilan secara acak jurnal yang akan dijadikan referensi serta berhubungan dengan tema penelitian. 


\subsection{Metode}

Metode penelitian yang digunakan adalah review beberapa jurnal yang berkaitan dengan tema penelitian yang berkenaan dengan logistik halal. Hasil review beberapa jurnal dibagi dalam sub tema penelitian, yaitu konsep tentang logistik halal, strategi pengembangan logistik, dan inovasi dalam logistik halal. Sumber dalam penelitian ini berjumlah 21 buah yang terdiri dari: 3 buah prosiding dan 18 buah jurnal. Kriteria inklusi dalam penelitian ini adalah halal logistik, integritas produk halal, manajemen pengetahuan dan pendekatan logistik 1 PL, 2 PL, 3 PL, 4 PL dan 5 PL serta inovasi dalam logistik.

\section{Hasil dan diskusi}

\subsection{Hasil}

Logistik halal merupakan salah satu faktor yang berperan penting dalam melakukan pengangkutan (transportasi) produk makanan dan minuman berlogo halal sampai ke tempat penjualan. Pelayanan logistik memerlukan pengembangan agar pelayanan menjadi berkualitas dengan penggunaan teknologi, konsep, dan kebijakan yang tepat. Hasil review jurnal menunjukkan ada beberapa konsep yang dapat digunakan dalam pengembangan logistik halal. Konsep pengembangan ini dimulai dari kerangka konsep dari logistik halal, inovasi, sertifikasi dan hambatan yang terjadi. Berikut penjelasan dari keempat konsep tersebut dari berbagai literatur.

\subsubsection{Kerangka konsep logistik halal}

Kerangka konsep ini berperan penting dalam peningkatan pelayanan logistik halal. Dengan adanya kerangka konsep ini, arah kebijakan serta perencanaan distribusi barang menjadi baik sehingga berpengaruh pada layanan dan profit perusahaan. Menurut Zulfakar dkk., konsep dalam melakukan penyediaan rantai pasok makanan halal dipengaruhi oleh 4 faktor, yaitu ketertelusuran produk yang dihantarkan, spesifisitas aset, quality assurance (pengendalian mutu produk), kepercayaan dan komitmen dari penyedia layanan tersebut [4]. Faktor ini membuat suatu sistem rantai pasok yang terintegritas dan bersifat transparan dalam pengiriman. Selain itu, dengan adanya pengendalian mutu produk ini dapat menjamin kualitas dan sertifikasi halal dari produk yang dipasarkan. Konsep tersebut dapat dilihat pada Gambar 1.

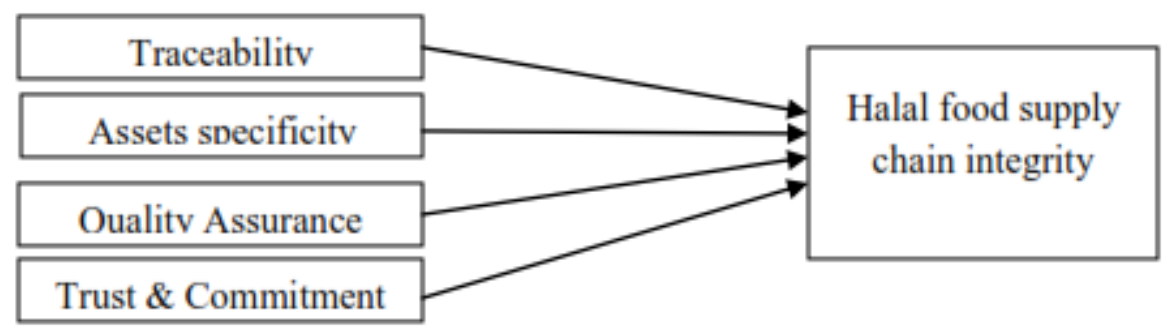

Gambar 1. Kerangka konsep integritas rantai pasok produk halal [4].

Gambar tersebut menunjukkan bahwa konsep ini memastikan adanya integritas dalam siklus rantai pasok. Konsep integritas dalam siklus rantai pasok distribusi makanan halal ini sangat penting dalam melakukan pemisahan dari bahan mentah, bungkus, hingga penyimpanan agar tidak tercampur dengan produk non-halal. Menurut Soon, efektivitas 
dalam integritas produk halal dalam perdagangan internasional atau antarnegara adalah transparansi dari penyedia produk, pengambil kebijakan, sertifikasi produk dan badan sertifikasi produk tersebut [5].

Jaafar dkk. mengembangkan konsep tentang logistik halal berdasarkan pada integritas produk halal yang dapat dilihat pada Gambar 2. Dalam konsep ini, integritas produk halal dipengaruhi oleh dua faktor, yaitu kelayakan sagregasi produk (proper sagregation) dan sistem logistik [6]. Sagregasi produk merupakan proses dalam pengendalian, pengepakan, transportasi, dan penyimpanan produk halal. Integritas produk halal, sagregasi produk dan sistem logistik yang baik merupakan komponen dalam membentuk logistik halal sehingga produk yang dipasarkan dapat dikonsumsi dan tidak tercampur dengan produk non-halal. Konsep tersebut didukung oleh prinsip yang telah disepakati secara bersama dalam logistik halal, yaitu mendefinisikan kontaminasi silang antara halal, haram, dan bagaimana cara dalam menghindarinya, menciptakan evolusi nilai pasok, menciptakan sistem dalam logistik halal, meminalisasi kesulitan dalam industri halal, melakukan studi banding terhadap sistem logistik halal yang sudah ada, serta melakukan standarisasi internasional [7]. Konsep studi banding merupakan pembelajaran yang baik dalam menjaga keamanan makanan halal yang dikonsumsi. Pembelajaran ini berkaitan dengan standarisasi logistik dari produksi, distribusi sampai transportasi produk. Salah satu negara yang dapat menjadi pembelajaran yang baik dalam standarisasi produk halal adalah Malaysia.

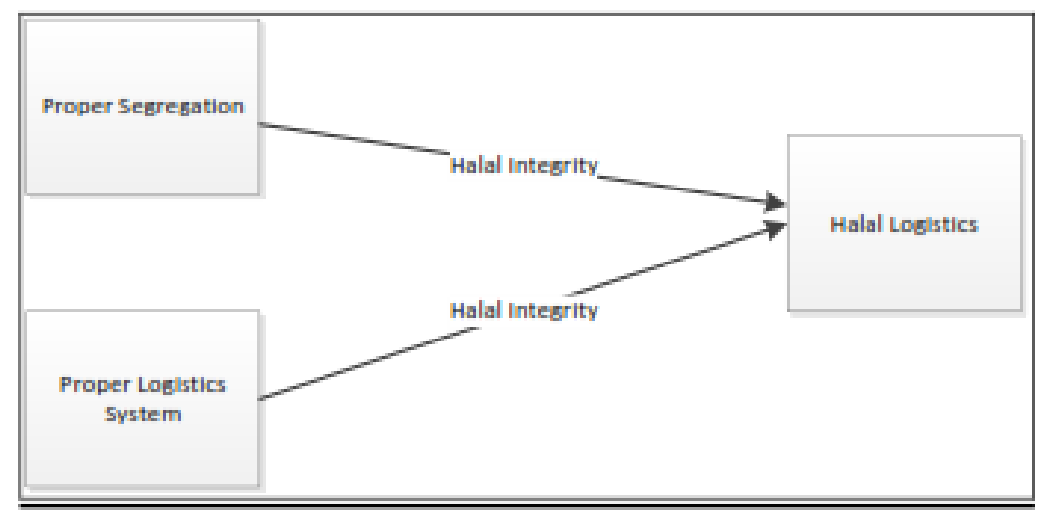

Gambar 2. Kerangka konsep halal logistik [6].

Malaysia menerapkan konsep sertifikasi yang telah diakui oleh dunia dengan menerapkan sertifikasi pada dunia industri, di mana perusahaan harus melengkapi dokumen, kondisi gudang serta penerapan manajemen yang baik. Gudang yang telah tersertifikasi halal hanya berisi makanan atau produk halal saja dan dibersihkan dengan metode sertu. Dokumentasi halal dalam konsep sertifikasi di Malaysia terus diperbarui dan disesuaikan dengan perkembangan secara global dalam dunia logistik [8]. Dalam hal konsumsi makanan halal, masyarakat Indonesia masih menaruh kepercayaan pada label produk tanpa memerhatikan keamanan dalam proses distribusi, penyimpanan, dan transportasi. Faktor yang berpengaruh pada masyarakat Indonesia untuk mengonsumsi barang halal adalah persepsi kesadaran, kebiasaan, identitas diri dan agama, kewajiban moral dan kepercayaan [9].

\subsubsection{Strategi pengembangan halal logistik}


Strategi merupakan pendekatan yang berkaitan dengan pelaksanaan aktivitas yang telah direncanakan agar pencapaian yang dihasilkan dapat lebih baik. Untuk itu, logistik halal memerlukan strategi dalam mencapai target kepuasan konsumen dan keuntungan dari sisi bisnis bagi industri pemasok. Berikut strategi dalam pengembangan halal logistik.

a) PL, 4 PL dan 5 PL (Party Logistic)

Strategi ini termasuk dalam sistem manajemen logistik yang melibatkan banyak aspek dalam aktivitasnya. Dalam strategi ini, ada 4 tingkatan menurut definisinya, yaitu first party (pabrik, grosir, pengecer dan pengirim barang), second party (merupakan bisnis yang dilakukan pelanggan pada pihak pertama atau first party), third party (perusahaan ekspedisi, penyedia layanan, operator gudang) dan fourth party (bisnis yang mengintegrasikan dan mengoordinasikan produk logistik dan arus proses informasi. Strategi 3 PL dan 4 PL ini melibatkan pihak luar (outsourcing). Pada $3 \mathrm{PL}$, perusahaan pemasok menyediakan transportasi dan penyimpanan. Sedangkan pada $4 \mathrm{PL}$, perusahaan pemasok memberikan pelayanan secara profesional dalam memecahkan masalah rantai pasok yang kompleks [10].

Strategi 4 PL merupakan perluasan dari 3 PL yang dalam pelayanannya 4 PL saling tumpang tindih dengan $3 \mathrm{PL}$. Strategi $4 \mathrm{PL}$ lebih menguntungkan karena perusahaan-perusahaan ini memberikan biaya konsultasi. Pada saat ini, perusahaan yang menggunakan strategi $3 \mathrm{PL}$ berusaha untuk berubah menjadi 4 PL agar dapat meningkatkan kepuasan layanan yang lebih pada pelanggan. Dalam strategi $4 \mathrm{PL}$, perusahaan rekanan telah menyediakan layanan yang berkaitan dengan teknologi informasi dan mengontrak perusahaan yang berada pada level 2 PL dan 3 PL. Kemudian, ada strategi 5 PL yang berfokus dalam pemberian solusi logistik secara keseluruhan dalam rantai pasok [11].

Pendekatan dengan strategi 5 PL merupakan strategi baru dalam sistem logistik rantai pasok. Strategi 5 PL menyebabkan terjadinya perubahan dalam sistem rantai pasok dan ada tiga dorongan yang menyebabkan terjadinya $5 \mathrm{PL}$, yaitu: peningkatan tren sistem rantai pasok pada perusahaan rekanan, pengaplikasian teknologi informasi dalam sistem rantai pasok (efisien dalam model transportasi, meningkatkan teknologi pergudangan, sistem teknologi pelabuhan), dan mengubah lanskap penyedia layanan logistik. Untuk itu, perusahaan layanan berbasis 5 PL mampu mengurangi biaya logistik, menurunkan tingkat persediaan dan menaikkan respon terhadap konsumen [12].

(b) Knowledge management (manajemen pengetahuan)

Strategi yang kedua dalam mengembangkan sistem logistik adalah manajemen pengetahuan. Manajemen pengetahuan mengombinasikan antara perangkat, teknik, dan strategi dalam mempertahankan, menganalisis, mengorganisasi, meningkatkan, berbagi pengertian serta pengalaman. Peningkatan manajemen pengetahuan dalam suatu organisasi memerlukan pemimpin yang mampu meningkatkan kinerja organisasi serta menciptakan budaya belajar dalam organisasi. Dalam suatu studi, budaya belajar dan manajemen pengetahuan ini berkorelasi dengan pengembangan modal manusia dan kinerja organisasi. Pengembangan modal manusia dapat dilakukan dengan pelatihan dan transfer pengetahuan [13]. 
Peningkatan pelatihan dan transfer pengetahuan pada staf maupun pemimpin dapat meningkatkan kinerja organisasi, terutama yang berkaitan dengan logistik. Peran penting manajemen pengetahuan dalam logistik adalah meningkatkan komunikasi, negosiasi, dan kemampuan dalam manajemen [14]. Melalui peningkatan kemampuan pada staf, kreativitas dan pengembangan teknologi baru dalam melakukan penciptaan teknologi logistik turut meningkat.

\subsubsection{Inovasi logistik halal}

Inovasi merupakan cara dalam pengembangan sistem dan konsep logistik halal. Penggunaan inovasi berkaitan dengan penggunaan teknologi agar dapat menciptakan kemudahan dalam pelacakan keamanan. Pengembangan inovasi bermanfaat untuk meningkatkan pelayanan logistik halal dalam rangka memenuhi kebutuhan produk halal yang terus meningkat. Peningkatan pelayanan produk halal dimulai dari implementasi secara komprehensif penyedia jasa logistik terhadap produk halal dengan cara melakukan segregasi, menerapkan layanan logistik yang berdedikasi penuh untuk produk halal, dan memahami tugas dan fungsi dari segregasi dan dedikasi untuk menetapkan rantai pasok dalam menghadapi tantangan dalam penanganan, penyimpanan, dan pengiriman [15].

Perkembangan teknologi dan permintaan produk halal yang tinggi membuat perusahaan penyediaan jasa logistik menciptakan inovasi dalam pelayanan agar meningkatkan nilai perusahaan tersebut. Salah satu inovasi teknologi yang berkembang dan berkaitan dengan logistik halal adalah blockchain. Studi menyatakan bahwa blockchain merupakan buku besar digital, terdesentralisasi, dan terdistribusi yang mencatat dan menambahkan transaksi dalam urutan kronologis dengan tujuan membuat catatan permanen dan tahan kerusakan [16]. Selain itu, sistem blockchain mempermudah industri halal dalam memisahkan produk halal dan haram serta mempermudah terjadinya transaksi serta kontrak secara digital.

Blockchain mempunyai 4 prinsip, yaitu database terdistribusi (seluruh pihak yang ada di blockchain memiliki akses ke seluruh database dan riwayat lengkapnya), transmisi peer to peer (komunikasi dua arah antara node satu ke node lainnya), transparansi tanpa adanya pseudonimitas (alamat palsu), pencatatan yang tidak berulang, dan komputasional logis [17]. Prinsip ini memungkinkan blockchain memberikan manfaat yang besar bagi industri dalam melakukan logistik halal. Manfaat yang didapatkan dalam penggunaan blockchain adalah meningkatkan efisiensi rantai pasok, penelurusan yang cepat dan akurat, realibilitas dan transparansi, meningkatkan manajemen kualitas pangan dan keuntungan bagi seruh penyedia pada rantai pasok atau logistik. Selain dari keuntungan, penggunaan blockchain ini memberikan tantangan tersendiri dalam penggunaannya, yaitu kompleksitas dalam integrasi, penerapan teknologi blockchain yang masih rendah, investasi yang besar, karakteristik teknologi blockchain dan tidak adanya regulasi serta standar secara global [18].

Penggunaan blockchain memerlukan struktur dan database yang harus dibangun secara baik agar dapat memenuhi kualitas dan standarisasi. Struktur dan database dapat terintegrasi dengan badan akreditasi halal pada setiap negara. Integrasi sistem ini dimulai dari pabrik penyedia produk sampai transportasi. Dengan integrasi sistem ini, semua pihak bisa melihat seluruh proses penyediaan produk halal termasuk badan sertifikasi. Integrasi rantai pasok produk halal dengan sistem blockchain ditunjukkan oleh Gambar 3. 


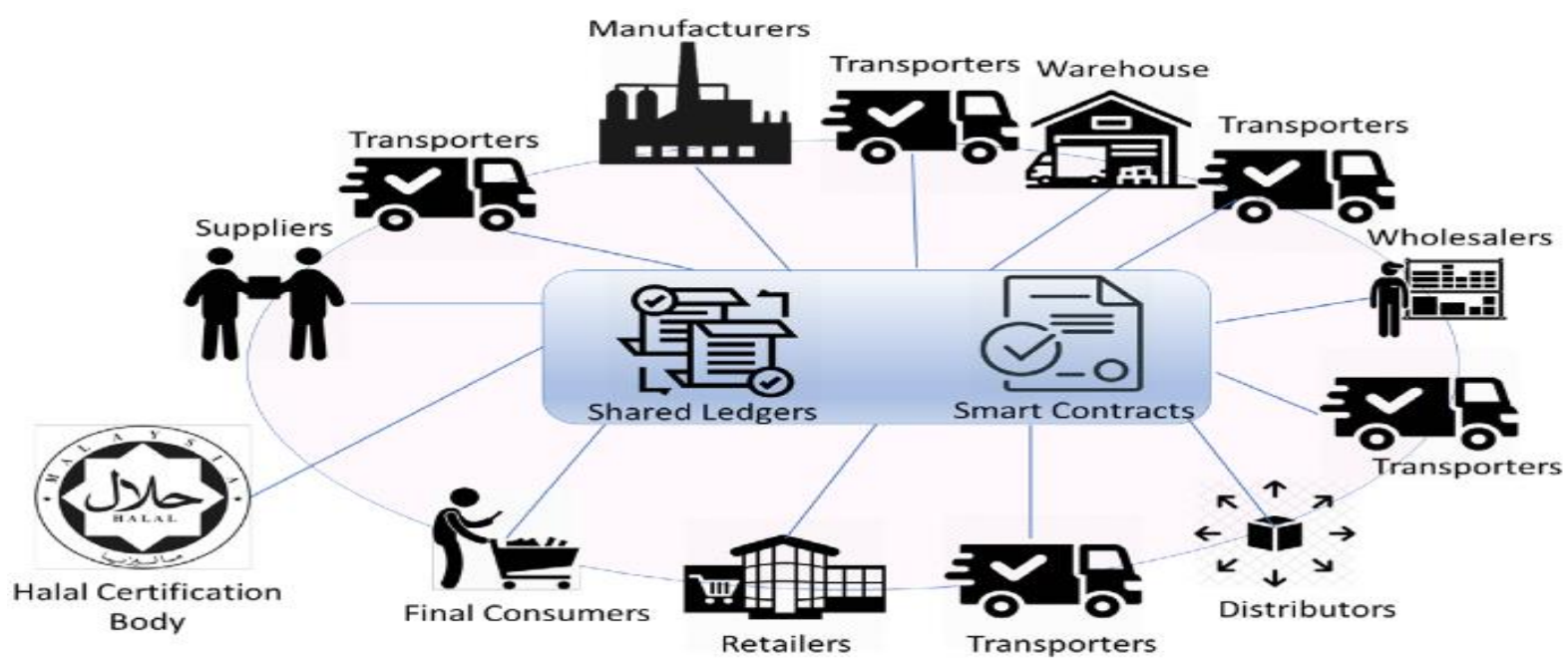

Gambar 3. Integrasi dalam rantai pasok produk halal dengan blockchain [19].

Gambar 3 menunjukkan seluruh proses rantai pasok produk halal yang terintegrasi dan memungkinkan seluruh pihak yang terlibat dalam proses ini dapat mengakses seluruh informasi yang terdapat dalam siklus. Contoh penggunaan aplikasi terintegrasi tersebut adalah pemotongan hewan yang dijadikan produk. Pada proses ini, seluruh pihak yang ada dalam siklus dapat mengakses informasi tentang pemeriksaan kesehatan hewan tersebut sampai pada proses pemotongan hewan sesuai dengan ajaran pada masyarakat muslim. Selain dari akses transparansi informasi, teknologi blockchain dapat digunakan untuk melakukan pelacakan atau penelusuran dari sertifikasi bahan mentah sampai produk akhir. Alur pelacakan rantai pasok produk halal dengan sistem blockchain dapat dilihat pada Gambar 4.

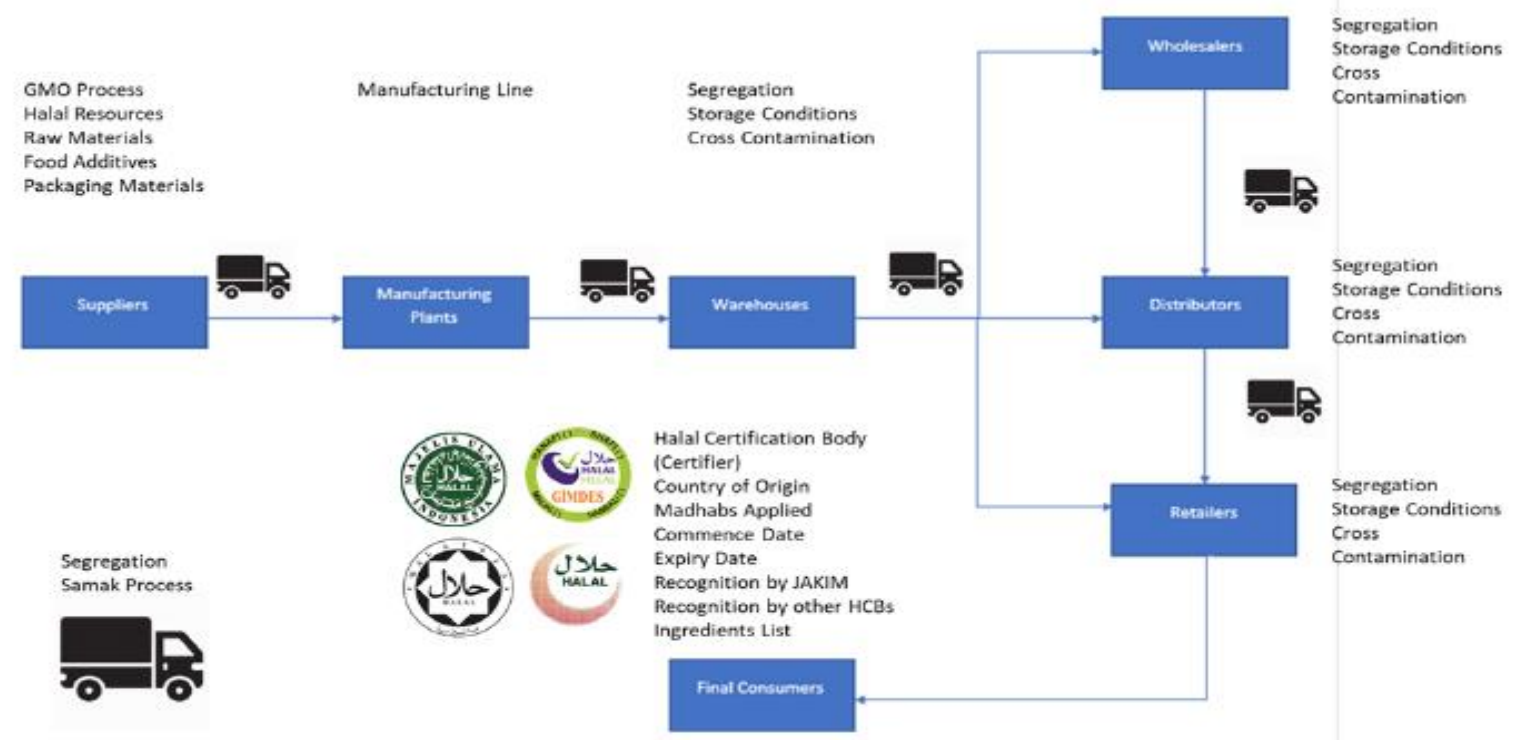

Gambar 4. Sistem pelacakan produk halal dengan sistem blockchain [19].

Gambar 4 menunjukkan bahwa sertifikasi produk halal dimulai dari penyedia barang sampai distribusi ke masyarakat. Sistem pelacakan ini menggunakan DNA sensor untuk mengecek daging yang akan didistribusikan ke konsumen dan memastikan tidak ada kontaminasi 
silang. Inovasi blockchain dalam melakukan pelacakan dapat bermanfaat dalam melakukan pengontrolan terhadap kontrol impor dan integritas produk halal [19]. Indonesia telah mengembangkan sistem pelacakan dengan blockchain dengan mengintegrasikan antara pelaku bisnis, pelaku produk halal, dan pemerintah yang ditunjukkan oleh Gambar 4. Berbeda dengan sistem pelacakan yang ada di Malaysia (Gambar 4), sistem pelacakan di Indonesia menggunakan identifikasi dan otomatisasi dengan barcode, serta identifikasi frekuensi radio (RFID) [20].

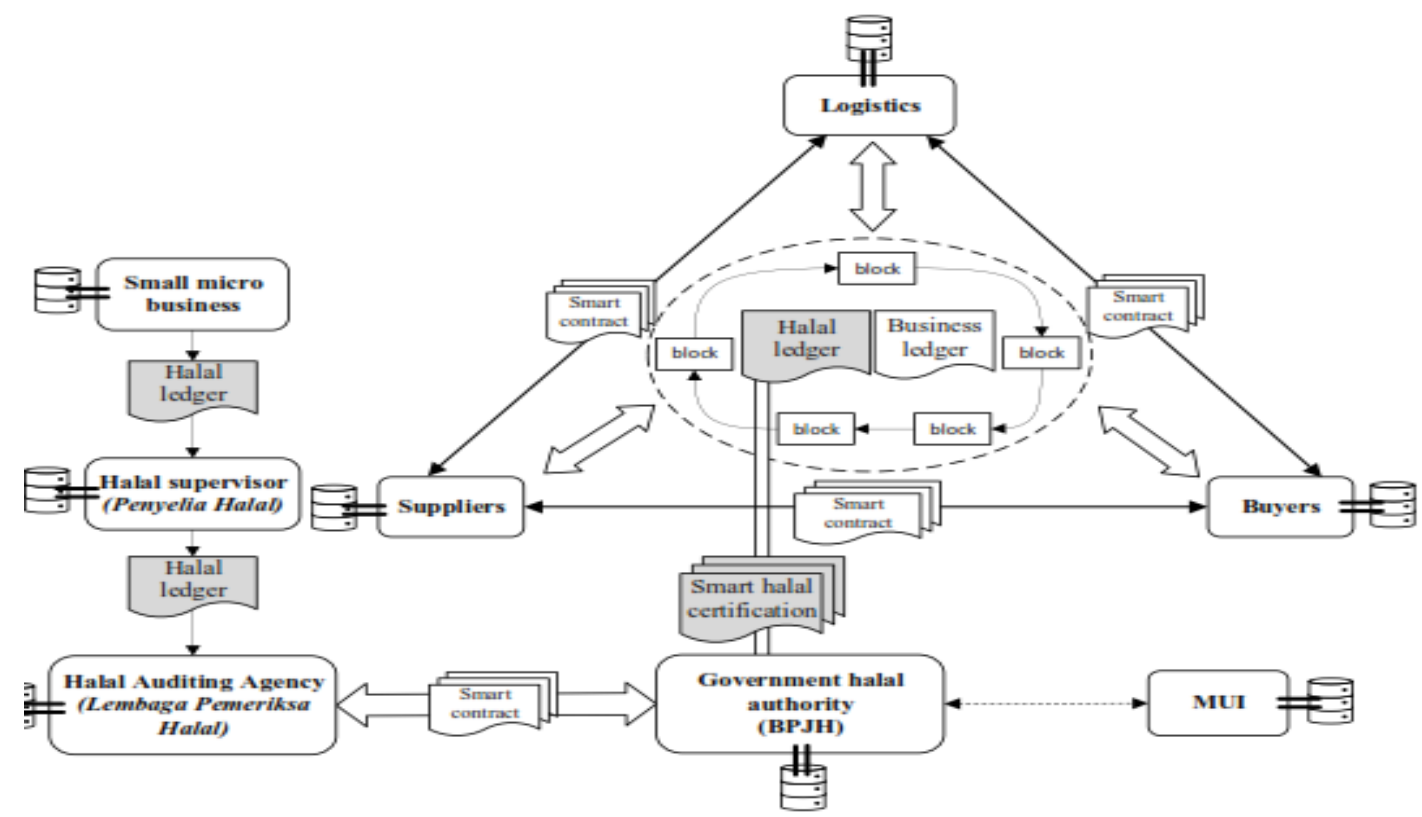

Gambar 5. Pengembangan sistem pelacakan integritas produk halal di Indonesia [20].

Gambar 5 menunjukkan bahwa sistem pengembangan Indonesia sudah sampai ke sertifikasi pada MUI dan BPJH, selaku otoritas pemerintah dalam pemberian sertifikat halal pada produk yang masuk ke Indonesia. Sistem pelacakan di Indonesia pada Gambar 5 hampir sama dengan sistem pelacakan produk halal di Malaysia (Gambar 4). Perbedaan kedua sistem ini terdapat pada sertifikasi pada saat produk tersebut berada di pergudangan dan distribusi. Permasalahan dalam melakukan implementasi terhadap penerapan teknologi blockchain yang ada di Indonesia terdapat pada komitmen antar stakeholders, rendahnya kewaspadaan konsumen terhadap produk halal dan tidak adanya perlindungan hukum [21].

\subsection{Diskusi}

Halal logistik merupakan faktor yang berperan penting dalam sistem rantai pasok produk, baik makanan maupun minuman halal. Pengembangan sistem halal logistik dapat meningkatkan kualitas penyimpanan, transportasi, kepuasan pelanggan, dan keuntungan dari sisi bisnis. Faktor yang berperan penting dalam pengembangan halal logistik seperti tersaji pada Gambar 2 dan 3, yaitu integritas produk halal, segregrasi kelayakan produk, dan kelayakan sistem logistik. Konsep integritas produk seperti tersaji pada Gambar 2 dipengaruhi oleh ketelusuran produk, spesifikasi aset, pengendalian mutu, kepercayaan dan komitmen. Ketelusuran produk berguna untuk menjamin transparansi pengiriman produk yang dilakukan oleh perusahaan penyedia jasa logistik dan pengendalian mutu, serta menjamin bahwa produk tersebut halal dan tidak terkontaminasi dengan produk non-halal. 
Aspek terpenting dalam integritas halal adalah kontaminasi produk dalam penyimpanan dengan produk non-halal. Untuk itu, perusahaan penyedia logistik harus memastikan kebersihan ruang penyimpanan. Salah satu contoh implementasi dari kebersihan penyimpanan ini dilakukan oleh Malaysia yang menetapkan standarisasi sertu dimulai dari bahan mentah, produk, proses, pencatatan hingga orang yang membawa produk tersebut. Standarisasi sertu ini masuk dalam kategori rantai pasok halal toyyiban dalam kargo/ transportasi produk ke konsumen. Adopsi pembersihan dengan sertu ini dapat diterapkan di Indonesia agar makanan yang dikonsumsi aman dan terhindar dari bahan makanan nonhalal. Pembersihan tersebut juga dimaksudkan untuk infrastruktur dari gudang tersebut, seperti lantai, forklift, ruang penyimpanan, dan truk pengangkut barang. Hubungan integritas produk halal dan logistik halal dapat dibuktikan dalam penelitian selanjutnya secara empiris, terutama kontaminasi pada penyimpanan produk. Namun, penelitian yang melakukan pengujian terhadap kontaminasi pada penyimpanan produk masih terbatas.

Strategi yang tepat dalam mengembangkan halal logistik adalah integrasi pendekatan $5 \mathrm{PL}$ (Party Logistic) dengan manajemen pengetahuan. Pendekatan $5 \mathrm{PL}$ ini lebih baik dibandingkan dengan 3 PL maupun $4 \mathrm{PL}$ dan dapat dijadikan pendekatan baru dalam meningkatkan kualitas logistik. Dalam pendekatan $5 \mathrm{PL}$, perusahaan penyedia jasa logistik dapat mengembangkan inovasi teknologi informasi untuk membuat biaya logistik lebih efisien. Integrasi pendekatan 5 PL dengan manajemen pengetahuan dapat meningkatkan kemampuan sumber daya manusia dan mendapatkan informasi serta isu terbaru yang berkaitan dengan logistik, termasuk pengetahuan tentang pengelolaan penyimpanan dan transportasi produk halal. Pengembangan teknologi informasi dari pendekatan 5 PL dapat memberi pelatihan dan berbagi pengetahuan secara cepat, baik secara virtual maupun tatap muka secara langsung. Selanjutnya, keterkaitan antara pendekatan 5 PL dan manajemen pengetahuan dapat diuji melalui penelitian selanjutnya dan dibuktikan secara empiris pengaruh pendekatan 5 PL terhadap manajemen pengetahuan.

Pengembangan logistik halal dapat dilakukan dengan menggunakan teknologi blockchain. Teknologi blockchain dapat mempermudah pemerintah, pelaku usaha halal, dan penyedia produk dapat melakukan pelacakan dan menerima informasi yang transparan. Negara Malaysia menjadi contoh terbaik dalam peningkatan dan pengembangan sistem pelacakan dengan menggunakan teknologi blockchain. Sistem teknologi blockchain di negara Malaysia sudah kompleks dan sertifikasi terhadap produk halal sudah meliputi seluruh aspek dimulai dari penyedia jasa, distribusi, pergudangan sampai ke penjualan produk tersebut.

Indonesia (Gambar 5) telah mengembangkan teknologi blockchain dengan sistem pelacakan yang sama dengan Malasyia, tetapi memiliki perbedaan pada sertifikasi pergudangan dan distributor. Selain itu, pengembangan ini memerlukan payung hukum terkait isu keamanan atau sekuritas data yang dimasukkan ke dalam sistem. Kejahatan siber telah menjadi isu utama dalam pengembangan aplikasi blockchain karena melibatkan perdagangan antarnegara. 


\section{Kesimpulan}

Manajemen rantai pasok merupakan sistem dalam melakukan pemasaran dan penyimpanan produk dalam gudang. Salah satu manajemen rantai pasok yang penting adalah logistik atau penghantaran produk kepada konsumen. Faktor yang paling penting dalam pengembangan logistik ini adalah kerangka konsep dan strategi dalam halal logistik. Kerangka konsep yang pertama dalam pengembangan logistik halal adalah integritas produk halal. Integritas produk halal berhubungan dengan ketelusuran produk, spesifisitas aset, pengendalian mutu, kepercayaan, dan komitmen. Konsep yang kedua adalah kelayakan segregasi produk dan sistem logistik dalam halal logistik.

Strategi untuk pengembangan halal logistik ada 5 klasifikasi yaitu $1 \mathrm{PL}, 2 \mathrm{PL}, 3 \mathrm{PL}, 4 \mathrm{PL}$ dan 5 PL. Setiap klasifikasi ini mempunyai peran, definisi, dan fungsi yang berbeda satu dengan yang lainnya. Selanjutnya adalah manajemen pengetahuan yang berperan meningkatkan kemampuan pegawai dan berbagi pengetahuan serta teknologi sehingga meningkatkan kinerja organisasi. Secara keseluruhan, menurut penulis, aspek yang terpenting dalam pengembangan halal logistik adalah integritas produk halal dan strategi dalam meningkatkan kemampuan dan kualitas logistik.

Selain itu, teknologi blockchain menjadi alternatif dalam melakukan inovasi dalam mengembangkan logistik halal. Pengembangan ini meliputi sertifikasi dari penyedia produk sampai ke penjual produk tersebut. Sertifikasi pada pergudangan, distributor, dan penjual dapat menjadi komponen alternatif yang dapat ditambahkan pada sistem pelacakan produk halal di Indonesia. Selain itu, pengembangan sistem pelacakan dalam sistem logistik di Indonesia dapat menambahkan sistem sensor DNA untuk memastikan daging yang dikonsumsi oleh penduduk muslim aman dan halal. Sistem blockchain dapat bermanfaat bagi pemerintah dalam mengontrol ekspor produk halal di Indonesia.

Secara keseluruhan, aspek yang terpenting dalam kajian pengembangan logistik halal adalah integritas produk halal serta sanitasi atau pembersihan gudang dari kontaminasi dengan produk non-halal dengan sertu. Selain itu, pengembangan inovasi blockchain seperti pada Gambar 3 dan 4 dapat ditambahkan dalam sistem blockchain yang telah dikembangkan di Indonesia pada Gambar 5 serta pengembangan sistem logistik 5 PL dalam mempercepat dan menghemat biaya logistik dan inovasi secara berkelanjutan. Selanjutnya, pada masa mendatang perlu pengujian secara empiris tentang implementasi sistem inovasi blockchain pada Gambar 5 dengan penambahan pada Gambar 4 guna memperkuat integrasi konsep logistik halal pada Gambar 1 dan 2.

\section{Ucapan terima kasih}

Penulis mengucapkan terimakah kepada Kepala Badan Perencanaan Pembangunan Daerah Provinsi Kepulauan Bangka Belitung dan Kepala Bidang Sosial Budaya Badan Perencanaan Provinsi Kepulauan Bangka Belitung terhadap dukungan selama penulisan karya tulis ini.

\section{Referensi}

[1] R. Nkwood, "Global Halal Food \& Beverage Market | Trends, Share, Size 2020-2028," 2020. 
[2] LPPOM, "Data Statistika Produk Halal LPPOM MUI Indonesia 2012-2019," LPPOM MUI, 2020. [Online]. Available: https://www.halalmui.org/mui14/main/page/data-statistikproduk-halal-Ippom-mui-indonesia-2012-2019 [accessed Jan 25, 2021].

[3] S. Zailani, M. Iranmanesh, A. A. Aziz, and K. Kanapathy, "Halal logistics opportunities and challenges," J. Islam. Mark., vol. 8, no. 1, pp. 127-139, 2018.

[4] M.H. Zulfakar, F. Jie, and C. Chan, "Halal food supply chain integrity: From a literature review to a conceptual framework," Proc. 10th ANZAM Oper. Supply Chain Serv. Manag. Symp., no. 61 4, pp. 1-23, 2012.

[5] J.M. Soon, M. Chandia, and J. Mac Regenstein, "Halal integrity in the food supply chain," Br. Food J., vol. 119, no. 1, pp. 39-51, 2017, doi: 10.1108/BFJ-04-2016-0150.

[6] H.S. Jaafar, E.N. Omar, M.R. Osman, and N. Faisol, "The Concept of Halal Logistics - An Insight," in ICLT Conference, 2013, no. 1.

[7] M. Tieman, "Establishing The Principles In Halal Logistics," J. Emerg. Econ. Islam. Res., vol. 1, no. 1, pp. 19, 2013, doi: 10.24191/jeeir.v1i1.9115.

[8] I. Fazira, D. Harras, I. Aviastuti, R. Didiet, R. Hidayat, and S. Amonalisa, "Benchmarking of Malaysia certified halal warehouse to implement certified halal warehouse in Indonesia," Advance in Transportation and Logistics Research, vol.1, pp. 139-149, 2018.

[9] I. Vanany, J.M. Soon, A. Maryani, and B. M. Wibawa, "Determinants of halal-food consumption in Indonesia," J. Islam. Mark., vol. 11, no. 2, pp. 516-530, 2019, doi: 10.1108/JIMA-09-2018-0177.

[10] N. Karia and M.H.A.H. Asaari, "Halal business and sustainability: strategies, resources and capabilities of halal third-party logistics (3PLs)," Prog. Ind. Ecol. An Int. J., vol. 10, no. $2 / 3$, p. 286, 2016, doi: 10.1504/pie.2016.10003063.

[11] A.V. Vasiliauskas and G. Jakubauskas, "Principle and benefits of third party logistics approach when managing logistics supply chain," Transport, vol. 22, no. 2, pp. 68-72, 2007, doi: 10.1080/16484142.2007.9638101.

[12] P. Hosie, B. Sundarakani, A.W.K. Tan, and A. Koźlak, "Determinants of fifth party logistics (5PL): Service providers for supply chain management," Int. J. Logist. Syst. Manag., vol. 13, no. 3, pp. 287-316, 2012, doi: 10.1504/IJLSM.2012.049700.

[13] L.A. Cooper, R.J. Huscroft, E.R. Overstreet, T.B. Hazen, "Knowledge management for logistics service providers: the role of learning culture," Ind. Manag. Data Syst., vol. 116, no. 3, pp. 1-32, 2016, doi: 10.1108/IMDS-06-2015-0262.

[14] I.N., L. Yao, and J.K. Cheng, "A Review of Logistics Management Related Knowledge Management," Sci. Int., vol. 29, no. 2, pp. 527-531, 2017.

[15] H.Z. Jaafar, I.R. Endut, F. Nasruddin, and E. Normalina, "Munich Personal RePEc Archive Innovation in logistics services - halal logistics," in Proceeding of the 16th International Symposium on Logistics (ISL), 2011, no. 34665, pp. 844-855.

[16] H. Treiblmaier, "The impact of blockchain on the supply chain : a theory-based research 
framework and a call for action," J. Mater. Process. Technol., vol. 1, no. 1, pp. 1-8, 2018.

[17] F.C. Godoi, S. Prakash, and B.R. Bhandari, "ASEAN high value add red meat opportunities ASEAN infrastructure and just in time logistics," 2015.

[18] S. Chen, X. Liu, J. Yan, G. Hu, and Y. Shi, "Processes, benefits, and challenges for adoption of blockchain technologies in food supply chains: a thematic analysis," Inf. Syst. E-bus. Manag., 2020, doi: 10.1007/s10257-020-00467-3.

[19] R.S. Aquino, M. Lück, and H.A. Schänzel "A conceptual framework of tourism social entrepreneurship for sustainable community development," J. Hosp. Tour. Manag., vol. 37, no. July, pp. 23-32, 2018, doi: 10.1016/j.jhtm.2018.09.001.

[20] I. Vanany, N.A. Rakhmawati, S. Sukoso, and J.M. Soon, "Indonesian halal food integrity: Blockchain platform," in CENIM 2020 - Proceeding: International Conference on Computer Engineering, Network, and Intelligent Multimedia 2020, 2020, pp. 297-302, doi: 10.1109/CENIM51130.2020.9297968.

[21] G.T. Nugraha, R.D.R. Hidayat, T. Budiman, and A. Setiawan, "The Implementation of halal supply chain with private blockchain in Indonesia," Adv. Transp. Logist. Res., vol. 1, no. 1, pp. 174-186, 2018. 